\title{
Thyroid scintigraphy in three-year-old children with congenital hypothyroidism in correlation with neonatal TSH
}

\author{
Wyniki scyntygrafii tarczycy u trzyletnich dzieci z wrodzoną niedoczynnością \\ tarczycy w zależności od stężenia TSH w okresie noworodkowym
}

\author{
Majid Aminzadeh \\ Pediatric Department, School of Medicine, Ahvaz Jundishapur University of Medical Sciences, Ahvaz, Iran
}

\begin{abstract}
Introduction: A large number of congenital hypothyroidism $(\mathrm{CH})$ cases in Iran are transient. This study was designed to investigate the aetiology of permanent $\mathrm{CH}(\mathrm{PCH})$ by thyroid scintigraphy (TS) and its relationship with the first diagnostic thyrotropin (TSH). Material and methods: During 12 years (2005-2017) of CH screening in southwest Iran, all infants referred with the diagnosis of $\mathrm{CH}$ were followed until their third birthday, when they were re-evaluated for serum T4, TSH after discontinuing the treatment for 3-4 weeks. If the last test indicated a PCH state (TSH $>10 \mathrm{mU} / \mathrm{L}$ with any levels of T4), TS was performed, and, based on the results, the patients were categorised as agenesis, dysgenesis (sublingual, thyroglossal cyst), and normal/diffuse goitre (indicating dyshormonogenesis).

Results: After excluding all transient $\mathrm{CH}$ subjects, 224 permanent $\mathrm{CH}$ cases were enrolled (52.7\% female). Seasonal distributions were as follows: spring: $25.7 \%$, summer: $27.9 \%$, autumn: $20.3 \%$, and winter: $26.1 \%$. No significant differences were found between females and males and the different modes of delivery (55.4\% were delivered by caesarean section) regarding T4, TSH ( $p>0.05)$. Of a total of 213 performed scans, $20.7 \%$ had agenesis, $36.2 \%$ had dysgenesis, and $43.2 \%$ were normal or goitrous. Those with agenesis/dysgenetic thyroid had a lower T4 and a higher TSH than those with normal scans. However, the differences were not significant. Compared to those who had TSH $<40 \mathrm{mU} / \mathrm{L}$, patients with TSH $\geq 40 \mathrm{mU} / \mathrm{L}$ had $46 \%$ (95\% CI; 1.06-2.02) more risk of agenesis or dysgenesis in TS.

Conclusions: More than $40 \%$ of PCH are caused by dyshormonogenesis in Iran. Having a TSH $\geq 40 \mathrm{mU} / \mathrm{L}$ after the first week of life significantly raises the probability of thyroid agenesis/dysgenesis as the cause. (Endokrynol Pol 2019; 70 (1): 43-48)
\end{abstract}

Key words: congenital hypothyroidism; screening; thyroid dysgenesis; thyroid scintigraphy

\section{Streszczenie}

Wstęp. W populacji irańskiej wrodzona niedoczynność tarczycy $(\mathrm{CH})$ ma w wielu przypadkach charakter przemijający. Przedstawione badanie przeprowadzono w celu oceny etiologii trwałej $\mathrm{CH}(\mathrm{PCH})$ na podstawie scyntygrafii tarczycy oraz zależności między wynikami tego badania a stężeniem tyreotropiny (TSH) w pierwszym badaniu diagnostycznym.

Materiał i metody. W okresie 12 lat (2005-2017), w którym prowadzono przesiewowe badania pod kątem CH w południowo-wschodnim Iranie, wszystkie dzieci skierowane do ośrodka autorów obserwowano do ukończenia 3. roku życia, kiedy przeprowadzano ponowną ocenę stężenia w surowicy T4 i TSH po zaprzestaniu leczenia na 3-4 tygodnie. Jeśli ostatnie badanie sugerowało PCH (TSH >10 mj./l, niezależnie od stężenia T4), wykonywano scyntygrafię tarczycy i w zależności od wyniku przydzielano chorych do jednej z następujących kategorii: agenezja, dysgenezja (tarczyca podjęzykowa, torbiel przewodu tarczowo-językowego), tarczyca prawidłowa/wole guzkowe (wskazujące na dyshormonogenzę).

Wyniki. Po wykluczeniu z badania wszystkich dzieci z przemijającą $\mathrm{CH}$ do analizy włączono 224 przypadki trwałej $\mathrm{CH}(52,7 \%$ badanych było płci żeńskiej). Rozkład w zależności od pory roku był następujący: wiosna $-25,7 \%$, lato - 27,9\%, jesień - 20,3\%, zima — 26,1\% . Nie stwierdzono istotnych różnic w stężeniach T4 i TSH między dziewczętami i chłopcami ani różnymi typami porodu (55,4\% dzieci urodziło się przez cesarskie cięcie) ( $\mathrm{p}>$ 0,05). Spośród 213 dzieci, u których wykonanych scyntygrafię, u 20,7\% stwierdzono agenezję, u 36,2\% — dysgenezję, a u 43,2\% — prawidłową tarczycę lub wole. U dzieci z agenezja/dysgenezją tarczycy stężenie T4 było niższe, a stężenie TSH wyższe niż u dzieci z prawidłowym obrazem tarczycy w scyntygrafii. Jednak różnice nie były istotne statystycznie. Ryzyko stwierdzenia agenezji lub dysgenezji tarczycy w badaniu scyntygraficznym było o $46 \%$ wyższe (95\% CI; 1,06-2,02) u osób, u których stężenie TSH wynosiło $\geq 40 \mathrm{mj} . / \mathrm{w}$ porównaniu z osobami, u których stężenie TSH wynosiło $<40 \mathrm{mj} . / 1$.

Wnioski: Ponad 40\% przypadków PCH w Iranie jest spowodowanych dyshormonogenezą. Stężenie TSH $\geq 40$ mj./l po pierwszym tygodniu życia istotnie zwiększa prawdopodobieństwo, że przyczyną niedoczynności tarczycy jest agenezja lub dysgenezja tego narządu. (Endokrynol Pol 2019; 70 (1): 43-48)

Słowa kluczowe: wrodzona niedoczynność tarczycy; badania przesiewowe; dysgenezja tarczycy; scyntygrafia tarczycy

\section{Introduction}

Congenital hypothyroidism $(\mathrm{CH})$ was reported to be more prevalent in the Asian population [1]. A large number of cases were reported as transient [2, 3], possibly caused by maternal and/or environmental factors [4-6]. In these situations, the clinician must be careful to avoid unnecessary treatment while not losing any 
permanent $\mathrm{CH}$ subject [7]. According to most $\mathrm{CH}$ screening plans [8], a heal prick whole blood thyrotropin (TSH) measurement and, if needed, a confirmatory serum test for thyroxine (T4) and TSH are tests required for the diagnosis and the appropriate management of all neonates [1]. In screening programs for common congenital disorders, some additional investigations are included with different aims. Prevention of having another sick baby by genetic studies, similar to what is being performed for phenylketonuria, has no place in the $\mathrm{CH}$ program. However, determining the underlying aetiology and outcome by thyroid scintigraphy (TS) is of great importance $[9,10]$. Some researchers have investigated the $\mathrm{CH}$ aetiology by TS at the time of diagnosis [11, 12]. However, performing TS does not change the treatment plan during the early years of management. Nevertheless, if it reveals a dysplastic thyroid gland (absence or ectopic, usually a small sublingual gland), parents can be told that the infant will need lifelong therapy.

It is commonly recommended that all patients be re-evaluated [13] after their third birthday [14] (when the critical period of brain development has passed), with a short period of treatment discontinuation to confirm if they are permanent or transient [5]. This is the best opportunity to exclude transient subjects and leave other investigations only for those with permanent $\mathrm{CH}$.

Based on the high prevalence of $\mathrm{CH}$ in Iran where almost half of the cases have been transient $[15,16]$ and the popularity of consanguinity [17] is reported to have increased the $\mathrm{CH}$ prevalence mostly due to dyshormonogenesis rather than dysgenesis [18], this study was designed to determine the different aetiologies of permanent $\mathrm{CH}$ in this country, using thyroid scintigraphy (TS), and to investigate the relationship between the first diagnostic serum TSH and TS results.

This study is the biggest study regarding the case number and the study course, which helped determine the aetiology of permanent $\mathrm{CH}$ after excluding all transient subjects in an Asian country with a high rate of consanguinity. It shows the role of genetics as the cause of dyshormonogenesis as well as more severe thyroid dysfunction in patients with agenesis/dysgenesis compared to dyshormonogenesis.

\section{Material and methods}

The screening program for $\mathrm{CH}$ started in Iran in 2005. During 12 years of study (until 2017), all subjects with the diagnosis of $\mathrm{CH}$ (diagnosed by the author since early life or referred to the author at any age as a focal point and paediatric endocrine consultant) were studied.

The study was approved by the Ethics Committee of Ahvaz Jundishapur University of Medical Sciences
(AJUMS). There were no requirements for free and informed consent because there have been no changes in medical procedures such as additional blood sampling or imaging, and the participants were not identified. Moreover, no additional charges were imposed on the subjects. The author was the only focal point for the referral and follow-up of the screening program authorised by AJUMS.

They were followed up until their third birthday, and then re-evaluation was performed for thyroid function tests (T4, TSH) following a 3-4-week treatment discontinuation. At this stage, those who had normal TSH were labelled as transient $\mathrm{CH}$ and were followed with scheduled rechecks for two more years to make sure that there was no recurrence. Those who had TSH rising ( $>10 \mathrm{mU} / \mathrm{L}$ in the first or subsequent tests after levothyroxine discontinuation) were considered as permanent $\mathrm{CH}$ and were investigated by thyroid scintigraphy by technetium pertechnetate $99 \mathrm{~m}$ ( $\left.{ }^{\mathrm{Tc}-99 \mathrm{~m}} \mathrm{TS}\right)$. Based on the TS results, they were categorised as agenesis (absence of thyroid uptake), dysgenesis (hypoplastic, hemiagenesis, sublingual, submandibular, ectopic, or thyroglossal cyst), and dyshormonogenesis (normal location of thyroid with normal or increased size and technetium uptake) (Fig. 1). In four of the subjects, thyroid ultrasonography was performed instead, due to concerns about radiation or poor cooperation. A normal size of thyroid categorised them as dyshormonogenesis.

Data regarding sex, month and season of birth, mode of delivery (caesarean section, or vaginal delivery), birth order, first diagnostic serum T4, TSH level, third year re-evaluation TSH values, and the TS results were collected and analysed to find their relationships with the outcome.

$\mathrm{CH}$ subjects secondary to hypophyseal disorder were excluded from the study.

\section{Statistical analysis}

Statistical analysis of the data was performed using Statistical Package for the Social Sciences 16.0 (SPSS, Inc., Chicago, IL, USA, Microsoft) software. Results were expressed as mean \pm standard deviation. Student's t-test was used for the comparison of the means for numeric variables and the chi-square test for comparing the means for non-numeric variables. Relative risk index was used for risk assessment. P values $<0.05$ were considered as significant.

\section{Results}

During the study, 224 [118 female (52.7\%); female to male $=1.11$ ) subjects with confirmed permanent primary $\mathrm{CH}$ were enrolled. Seasonal distributions were as 


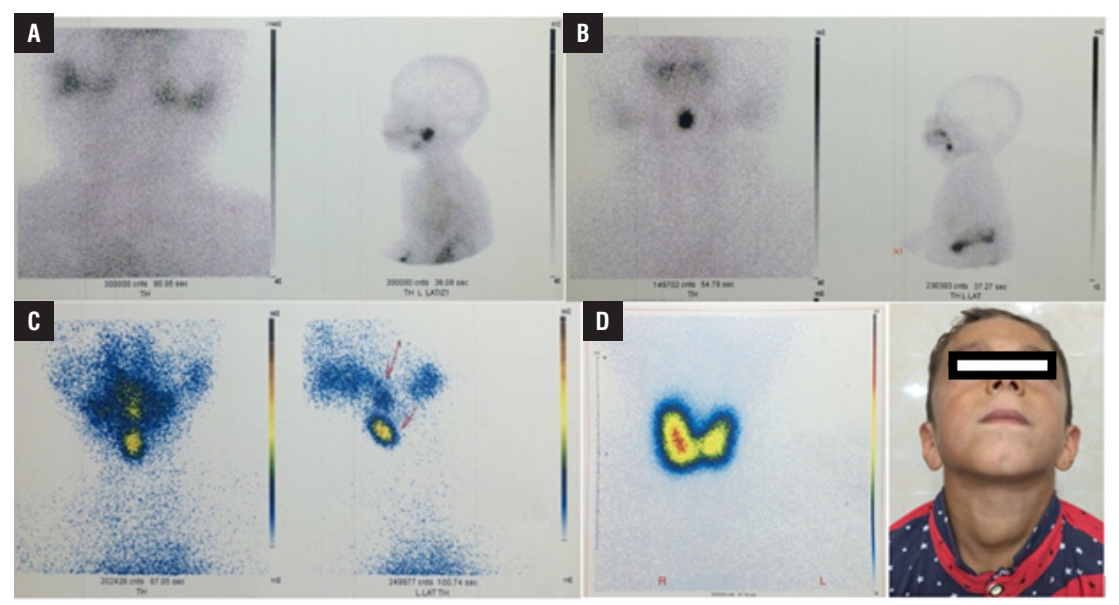

Figure 1. A. 3.5-year-old girl with TSH $=104.9 \mathrm{mU} / \mathrm{L}$ in neonatal confirmatory test, and $40.7 \mathrm{mU} / \mathrm{L}$ in re-evaluation. Scan showed no uptake at the bed of thyroid gland and no ectopic absorption at neck and oral cavity indicating congenital absence of thyroid. B. A 4-year-old girl with a TSH $=40 \mathrm{mU} / \mathrm{L}$ in neonatal confirmatory test and TSH $=289 \mathrm{mU} / \mathrm{L}$ in re-evaluation. Scan showed no uptake at the bed of thyroid gland but there was ectopic radiotracer absorption at oral cavity at the base of the tongue indicating lingual thyroid. C. A 3.5-year-old girl with TSH $=22.5 \mathrm{mU} / \mathrm{L}$ in neonatal confirmatory test and TSH $=23.7 \mathrm{mU} / \mathrm{L}$ at the three-year re-evaluation. Scan revealed ectopic radiotracer absorption at midline of upper neck as well as in oral cavity at the base of the tongue (arrows), but thyroid lobes were not visualised. Double thyroid ectopia, lingual and at the course of thyro-glossal duct was suggested. D. A 6-year, 10-month-old boy with confirmatory TSH $>100 \mathrm{mU} / \mathrm{L}$ and treatment since $30^{\text {th }}$ day of life. After discontinuation of levothyroxine TSH raised to $>100 \mathrm{mU} / \mathrm{L}$ and goitre was visible clinically. Scan revealed enlarged thyroid with increase and rather homogenous uptake of radiotracer of both lobes indicating dyshormonogenesis (parental consent obtained for photography)

Rycina 1. A. Dziewczynka w wieku 3,5 roku, u której wynik badania stężenia TSH w okresie noworodkowym wynosił 104,9 mj./l, a wynik ponownego badania - 40,7 mj./l. W badaniu scyntygraficznym stwierdzono brak wychwytu w toży tarczycy oraz brak ektopowej absorpcji w obrębie szyi i jamy ustnej, co świadczy o wrodzonym braku tarczycy. B. Dziewczynka w wieku 4 lat, u której wynik badania stężenia TSH w okresie noworodkowym wynosit $40 \mathrm{mj} . / \mathrm{l}$, a wynik powtórnego badania — $289 \mathrm{mj} . / \mathrm{l}$. W badaniu scyntygraficznym stwierdzono brak wychwytu w toży tarczycy, lecz zaobserwowano ektopowa absorpcje radioznacznika w jamie ustnej u podstawy języka, co wskazuje na obecność tarczycy językowej. C. Dziewczynka w wieku 3,5 roku, u której wynik badania stężenia TSH w okresie noworodkowym wynosit 22,5 mj./l, a wynik ponownego badania - 23,7 mj./l. W badaniu scyntygraficznym stwierdzono ektopowa absorpcję radioznacznika w linii pośrodkowej w górnej części szyi oraz w jamie ustnej u nasady języka (strzałki), jednak płaty tarczycy nie zostaty uwidocznione. Sugerowano podwójna ektopię tarczycy: tarczyca językowa i zlokalizowana wzdłuż przebiegu przewodu tarczowo-językowego. D. Chłopiec w wieku 6 lat i 10 miesięcy, u którego wynik diagnostycznego oznaczenia TSH wynosit > 100 mj./l $i$ który był leczony od 30. dnia życia. Po zaprzestaniu podawania lewotyroksyny stężenie TSH wzrosło do > 100 mj./l, a wole było wyraźnie widoczne. W badaniu scyntygraficznym uwidoczniono powiększona tarczycę ze zwiększonym i raczej jednorodnym wychwytem radioznacznika w obu ptatach, co wskazuje na dyshormonogenezę (rodzice wyrazili zgodę na publikację zdjęcia)

follows: spring: $25.7 \%$, summer: $27.9 \%$, autumn: $20.3 \%$, and winter: $26.1 \%$.

With regard to the mode of delivery, $44.6 \%$ were born via normal delivery and $55.4 \%$ by caesarean section $(\mathrm{C} / \mathrm{S})$.

Regarding the birth order, $46.1 \%$ were the first, $32 \%$ the second, $11.7 \%$ the third, $5.8 \%$ the forth, $3.9 \%$ the fifth, and $0.5 \%$ the sixth child of their families. Of a total of 213 performed scans, 44 subjects $(20.7 \% ; \mathrm{F} / \mathrm{M}=24 / 20=1.2 / 1)$ had agenesis, 77 (36.2\%; $\mathrm{F} / \mathrm{M}=51 / 26=1.96 / 1)$ had dysgenesis, and $92(43.2 \%$; $\mathrm{F} / \mathrm{M}=38 / 54=0.7 / 1$ ) were normal or goitrous (indicating dyshormonogenesis) (Tab. I).

There were no significant differences between females and males regarding T4 as well as TSH at the time of diagnosis ( $p>0.05$ ). Infants born via $C / S$ had more serum values for both T4 and TSH (6.49 \pm 10.7 vs. $4.99 \pm 3.7$ and $109.38 \pm 165.7$ vs. $85.30 \pm 83.3$, respectively) but these differences were not significant ( $\mathrm{p}>0.05)$.

Compared to those who had normal scans, patients with thyroid agenesis/dysgenesis had lower T4 (4.8 \pm 3.5 vs. $7.65 \pm 12.8 \mathrm{mg} / \mathrm{dL})$ and higher TSH $(125.8 \pm 169.3$ vs. $103.5 \pm 118.5 \mathrm{mU} / \mathrm{L})$ but none was significant $(\mathrm{p}>0.05)$.

Compared to those who had TSH $<40 \mathrm{mU} / \mathrm{L}$, patients with $\mathrm{TSH} \geq 40 \mathrm{mU} / \mathrm{L}$ had a $46 \%(\mathrm{RR}=1.46$; CI 95\%: 1.06-2.02) higher risk of having abnormal TS results (Fig. 2).

\section{Discussion}

As was expected, higher neonatal serum TSH values were found in those with athyreosis/dysgenesis com- 
Table I. Classification of scintiscan results in 180 patients with permanent congenital hypothyroidism (CH) based on their first diagnostic TSH values

Tabela I. Klasyfikacja wyników scyntygrafii u 180 chorych z trwałą wrodzonq̨ niedoczynnościq tarczycy (CH) w zależności od wartości pierwszego diagnostycznego badania stężenia TSH

\begin{tabular}{lccccc}
\hline & & \multicolumn{3}{c}{ Final Scintiscan result } \\
\hline TSH value & Agenesis & Dysgenesis & All abnormal & Normal & Total \\
\hline$\geq 40^{*}$ & $40(30.1)^{* *}$ & $51(38.3)$ & $\mathbf{9 1 ( 6 8 . 4 )}$ & $\mathbf{4 2 ( 3 1 . 6 )}$ & $\mathbf{1 3 3 ( 1 0 0 )}$ \\
\hline$<40$ & $1(2.12)$ & $21(44.68)$ & $\mathbf{2 2 ( 4 6 . 8 )}$ & $\mathbf{2 5 ( 5 3 . 2 )}$ & $\mathbf{4 7}(\mathbf{1 0 0 )}$ \\
\hline $\mathbf{2 0 - 3 9 . 9}$ & $0(0)$ & $8(36.4)$ & $8(36.4)$ & $14(63.6)$ & $22(100)$ \\
\hline$<\mathbf{2 0}$ & $1(4)$ & $13(52)$ & $14(56)$ & $11(44)$ & $25(100)$ \\
\hline Total & $\mathbf{4 1 ( 2 2 . 8 )}$ & $\mathbf{7 2 ( 4 0 )}$ & $\mathbf{1 1 3 ( 6 6 . 8 )}$ & $\mathbf{6 7}(\mathbf{3 7 . 2})$ & $\mathbf{1 8 0 ( 1 0 0 )}$ \\
\hline
\end{tabular}

${ }^{*} \mathrm{mU} / \mathrm{L} ;{ }^{* *}$ Number in parenthesis shows the percentage in each TSH group

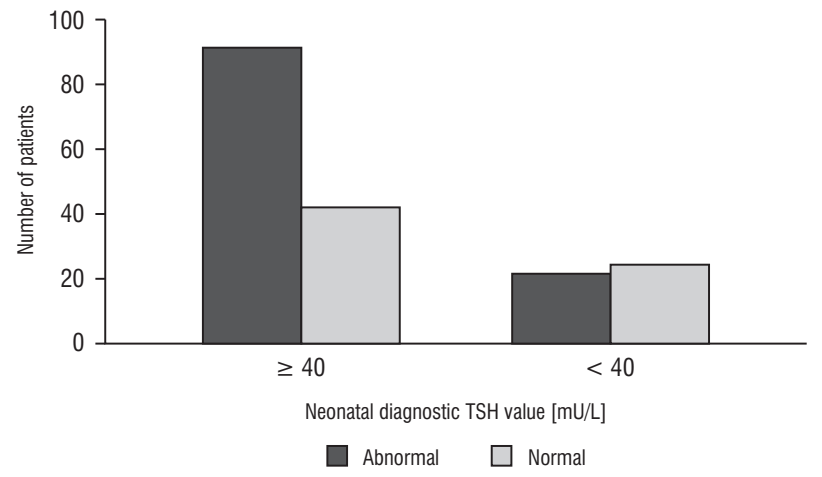

Figure 2. Distribution of abnormal (agenesis/dysgenesis) and normal results of thyroid scintiscan performed after the $3^{\text {rd }}$ birthday re-evaluation, in 180 patients with permanent congenital hypothyroidism, based on their first neonatal diagnostic TSH values

Rycina 2. Dystrybucja nieprawidtowych (agenezja/dysgenezja) i prawidłowych wyników powtórnych badan scyntygraficznych tarczycy wykonanych po ukończeniu 3 lat życia u 180 chorych $z$ trwała wrodzona niedoczynnościa tarczycy w zależności od stężenia TSH oznaczonego w czasie pierwszego badania diagnostycznego wykonanego w okresie noworodkowym

pared to subjects with dyshormonogenesis, indicating greater severity of the disorder and requiring serious follow-up in these subjects.
Iranpour et al. [11], in a study on 116 neonates with the diagnosis of $\mathrm{CH}$ requiring replacement levothyroxine treatment, performed early pre-treatment TS to classify them based on aetiology. They found that only $28.5 \%$ of them were athyreotic and $6 \%$ had dysgenesis; all the rest $(65 \%)$ had a normal scan result. This study showed a significantly higher TSH value in those with agenesis. Similarly to Iranpour's study [11], the author also found higher TSH levels in athyreotic subjects, but the distribution of our patients in the TS classification was different (Table II). The smaller percentage of normal scans ( $\approx 40 \%$ dyshormonogenesis) in our study was due to the exclusion of transient cases before scanning.

El-desouki et al. [12] in Saudi Arabia designed a study similar to the previously-mentioned study and performed scanning for $147 \mathrm{CH}$ patients. Their results were similar to our study (Tab. II).

Albert et al. reviewed the incidence of $\mathrm{CH}$ in $\mathrm{New}$ Zealand in a screening program covering 18 years [18]. Near two thirds of their cases were found to have dyshormonogenesis. An interesting point of their study was the increasing incidence of $\mathrm{CH}$ in New Zealand, mostly related to dyshormonogenesis. They explained this rise by the increase in Asian population immigration to New Zealand during that period.

Table II. The results and comparison of five studies investigated underlying cause of congenital hypothyroidism (CH) based on thyroid scintigraphy

Tabela II. Porównanie wyników uzyskanych w pięciu badaniach oceniających przyczyny wrodzonej niedoczynności tarczycy (CH) na podstawie badania scyntygraficznego

\begin{tabular}{|c|c|c|c|c|c|}
\hline Study & & Agenesis & Dysgenesis & Normal & No. ${ }^{* * *}$ \\
\hline Aminzadeh & 2018 & $20.7^{*}(1.2 / 1)^{* *}$ & $36.2(1.96 / 1)$ & $43.2(0.7 / 1)$ & 213 \\
\hline Albert et al [18] & 2012 & \multicolumn{2}{|c|}{$67(5 / 1)$} & $33(0.9 / 1)$ & 284 \\
\hline Iranpour [11] & 2006 & $28.4(0.8 / 1)$ & $6(1.3 / 1)$ & $65.6(1.5 / 1)$ & 116 \\
\hline Eugene et al [19] & 2005 & $16(1.4 / 1)$ & $68(3.25 / 1)$ & $15(0.69 / 1)$ & 148 \\
\hline El-desouki et al. [12] & 1995 & $22(1.67 / 1)$ & $42(2.26 / 1)$ & $36(1.2 / 1)$ & 147 \\
\hline
\end{tabular}

*Numbers show the percentage of total studied subjects. ${ }^{*}$ Numbers in the parenthesis show female-to-male ratio. ${ }^{* *}$ Total number of cases in each study 
Another study performed by Eugene et al. [19] on 148 permanent $\mathrm{CH}$ subjects in Quebec, Canada reported only $15 \%$ of normal scan results, matching with a pattern of $\mathrm{CH}$ aetiology in a typical western country, which was mostly caused by sporadic dysgenesis rather than familial genetically-based dyshormonogenesis. Table 2 shows a brief comparison of the five mentioned studies and their findings conducted in different countries.

Regarding the mode of delivery, $44.6 \%$ were born via vaginal delivery (VD) and $55.4 \%$ by caesarean section $(\mathrm{C} / \mathrm{S})$. This finding is close to what we see in the general population in Iran. This high prevalence of $\mathrm{C} / \mathrm{S}$ deliveries is related to women's preferences rather than obstetric issues.

Turan's study in Turkey [20] showed an insignificantly higher TSH value in neonates born via VD compared to those via $\mathrm{C} / \mathrm{S}$, but similar to the study of McElduff et al. [21]; our subjects with a history of C/S had a slightly higher mean for T4 and TSH, although these differences were not significant. After excluding personal interests, those with caesarean deliveries are likely to have valuable differences in this regard.

Regarding the birth order, $90 \%$ of the cases were born as the first, the second, or the third child of their families. This only showed a higher attitude of parents to have only one or two children at most. However, some studies [22] have reported a change in $\mathrm{CH}$ prevalence in different birth orders. In concordance with the study of Rosenthal [23], birth order in our $\mathrm{CH}$ subjects was not significantly different from that of the general population.

Seasonal distributions were found to be as follows: spring: $25.7 \%$, summer: $27.9 \%$, autumn: $20.3 \%$, and winter: $26.1 \%$. The author's previous study (6) in this region had disclosed a different pattern: spring: 19\%, summer: $13.4 \%$, autumn: $32.4 \%$, and winter: $35.2 \%$. In an opposite direction, Hashemipour et al. [24] reported a higher prevalence of $\mathrm{CH}$ in the warm season of the year. The two studies above had enrolled both transient and permanent $\mathrm{CH}$ patients, but the present research surveyed only permanent $\mathrm{CH}$ subjects. This may explain the aforementioned difference in seasonal patterns. Higher incidence of $\mathrm{CH}$ in cold or warm seasons of the year were related mostly to the aetiology of transient $\mathrm{CH}$, and the regular incidence of $\mathrm{CH}$ over the year in this study matches with the aetiologies of permanent $\mathrm{CH}$, not changing over the year.

\section{Study limitations}

In this study, all negative (no uptake) TS indexes were considered as agenesis, but there are some other possibilities. Absence of uptake can also be seen by TSHb gene mutations, TSH receptor inactivating mutations, iodide trapping defects, and maternal transfer of thyrotropin receptor blocking antibodies (TRB-Ab). Thyroid ultrasonography and other investigations such as the measurement of serum thyroglobulin or TRB-Ab will help differentiate these aetiologies from thyroid agenesis.

Actually, a combination of thyroid scan and ultrasonography provides maximal information to the clinician about thyroid function and its anatomic status. Then the real rate of dyshormonogenesis could be a little bit higher than what was reported in this study.

\section{Conclusions}

More than $43 \%$ of permanent $\mathrm{CH}$ subjects in Iran are caused by dyshormonogenesis. Compared to those with TSH $<40 \mathrm{mU} / \mathrm{L}$, higher values have greater risk of having abnormal thyroid structure.

\section{Acknowledgments}

This study was performed based on the research project (U-87010) supported by Ahvaz Jundishapur University of Medical Sciences (AJUMS). The author would like to thank all the health staff and physicians attending the $\mathrm{CH}$ screening program. The author also expresses thanks to Dr. Faramarz Ahmadi (assistant professor of nuclear medicine at AJUMS) for reporting the scintiscans and Dr. Bahman Cheraghian for his help with the statistics.

\section{Conflict of interest}

None declared.

\section{References}

1. Rastogi MV, LaFranchi SH. Congenital hypothyroidism. Orphanet J Rare Dis. 2010; 5: 17, doi: 10.1186/1750-1172-5-17, indexed in Pubmed: 20537182.

2. Karamizadeh Z, Dalili S, Sanei-Far H, et al. Does congenital hypothyroidism have different etiologies in Iran? Iran J Pediatr. 2011; 21(2): 188-192, indexed in Pubmed: 23056786.

3. Hashemipour M, Hovsepian S, Kelishadi R. Permanent and transient congenital hypothyroidism in Isfahan-Iran. J Med Screen. 2009; 16(1): 11-16, doi: 10.1258/jms.2009.008090, indexed in Pubmed: 19349525.

4. Hashemipour M, Nasri P,Hovsepian S, et al. Urine and milk iodine concentrations in healthy and congenitally hypothyroid neonates and their mothers. Endokrynol Pol. 2010; 61(4): 371-376, indexed in Pubmed: 20806181.

5. Parks JS, Lin M, Grosse SD, et al. The impact of transient hypothyroidism on the increasing rate of congenital hypothyroidism in the United States. Pediatrics. 2010; 125(Suppl 2): S54-S63, doi: 10.1542/peds.2009-1975F, indexed in Pubmed: 20435718.

6. Aminzadeh M, Chomeili B, Riahi K, et al. Effect of temperature changes on the occurrence of congenital hypothyroidism. J Med Screen. 2010; 17(3): 121-124, doi: 10.1258/jms.2010.010026, indexed in Pubmed: 20956721.

7. Kanike N, Davis A, Shekhawat PS. Transient hypothyroidism in the newborn: to treat or not to treat. Transl Pediatr. 2017; 6(4): 349-358, doi: 10.21037/tp.2017.09.07, indexed in Pubmed: 29184815.

8. Zinn AB. Inborn errors of metabolism. In: Martin RJ, Fanaroff AA, Walsh MC. ed. Neonatal-Perinatal Medicine: Diseases of the Fetus and Infant. 9 ed. . Elsevier Mosby, St. Louis 2011: 1621.

9. Schoen EJ, Clapp W, To TT, et al. The key role of newborn thyroid scintigraphy with isotopic iodide (123I) in defining and managing congenital hypothyroidism. Pediatrics. 2004; 114(6): e683-e688, doi: 10.1542/peds.2004-0803, indexed in Pubmed: 15574601. 
10. Park SM, Chatterjee VKK. Genetics of congenital hypothyroidism. J Med Genet. 2005; 42(5): 379-389, doi: 10.1136/jmg.2004.024158, indexed in Pubmed: 15863666.

11. Iranpour R, Hashemipour M, Amini $M$, et al. [Tc]-99m thyroid scintigraphy in congenital hypothyroidism screening program. J Trop Pediatr. 2006; 52(6): 411-415, doi: 10.1093/tropej/fml038, indexed in Pubmed: 16943215.

12. el-Desouki M, al-Jurayyan N, al-Nuaim A, et al. Thyroid scintigraphy and perchlorate discharge test in the diagnosis of congenital hypothyroidism. Eur J Nucl Med. 1995; 22(9): 1005-1008, indexed in Pubmed: 7588936

13. Léger J, Olivieri A, Donaldson M, et al. ESPE-PES-SLEP-JSPE-APEG-APPES-ISPAE, Congenital Hypothyroidism Consensus Conference Group. European Society for Paediatric Endocrinology consensus guidelines on screening, diagnosis, and management of congenital hypothyroidism. J Clin Endocrinol Metab. 2014; 99(2): 363-384, doi: 10.1210/jc.2013-1891, indexed in Pubmed: 24446653.

14. Maciel LM, Kimura ET, Nogueira CR. Congenital hypothyroidism: recommendations of the Thyroid Department of the Brazilian Society of Endocrinology and Metabolism. Arq Bras Endocrinol Metabol. 2013; 57(3): 184-192, indexed in Pubmed: 23681264.

15. Veisani Y, Sayehmiri K, Rezaeian S, et al. Congenital hypothyroidism screening program in iran; a systematic review and metaanalysis. Iran J Pediatr. 2014; 24(6): 665-672, indexed in Pubmed: 26019769.

16. Ghasemi M, Hashemipour M, Hovsepian S, et al. Prevalence of transient congenital hypothyroidism in central part of Iran. J Res Med Sci. 2013; 18(8): 699-703, indexed in Pubmed: 24379847.
17. Hashemipour M, Amini M, Talaie M, et al. Parental consanguinity among parents of neonates with congenital hypothyroidism in Isfahan. East Mediterr Health J. 2007; 13(3): 567-574, indexed in Pubmed: 17687829.

18. Albert BB, Cutfield WS, Webster D, et al. Etiology of increasing incidence of congenital hypothyroidism in New Zealand from 1993-2010. J Clin Endocrinol Metab. 2012; 97(9): 3155-3160, doi: 10.1210/jc.2012-1562, indexed in Pubmed: 22723332

19. Eugène D, Djemli A, Van Vliet G. Sexual dimorphism of thyroid function in newborns with congenital hypothyroidism. J Clin Endocrinol Metab. 2005; 90(5): 2696-2700, doi: 10.1210/jc.2004-2320, indexed in Pubmed: 15728201.

20. Turan S, Bereket A, Angaji M, et al. The effect of the mode of delivery on neonatal thyroid function. J Matern Fetal Neonatal Med. 2007; 20(6): 473-476, doi: 10.1080/14767050701398314, indexed in Pubmed: 17674257.

21. McElduff A, McElduff P, Wiley V, et al. Neonatal thyrotropin as measured in a congenital hypothyroidism screening program: influence of the mode of delivery. J Clin Endocrinol Metab. 2005; 90(12): 6361-6363, doi: 10.1210/jc.2005-0786, indexed in Pubmed: 16144951.

22. Razavi Z,Mohammadi L. Permanent and Transient Congenital Hypothyroidism in Hamadan West Province of Iran. Int J Endocrinol Metab. 2016 14(4): e38256, doi: 10.5812/ijem.38256, indexed in Pubmed: 28144251.

23. Rosenthal M, Addison GM, Price DA. Congenital hypothyroidism: increased incidence in Asian families. Arch Dis Child. 1988; 63(7): 790-793, indexed in Pubmed: 3415295.

24. Hashemipour M, Amini M, Kelishadi R, et al. Seasonal variation in the incidence of congenital hypothyroidism in Isfahan, Iran. Saudi Med J. 2007; 28(10): 1582-1586, indexed in Pubmed: 17914523. 